\title{
Vocabulary Prosperity: Words Concept of 'Mind Activities' in Javanese
}

\author{
Wiwin Erni Siti Nurlina \\ Balai Bahasa Daerah Istimewa Yogyakarta \\ ernibby@gmail.com
}

\begin{abstract}
In Javanese language, there is a series of word that can express the concept of mind neutrally. These words bear a resemblance meaning, but actually they have different elements of meaning. These differences result in variety of usages.These words include the word mikir 'to think', nalar 'to reason', neges 'to interpret', nggagas'to think about', nrawang 'to foresee', and ngreka 'to concoct'. Such diversity is the richness of the language lexicon concerned. To know the diversity of words with its richness of the concept of meaning, componential analysis was implemented by asserting meaning field theory of Indonesian and Javanese lexicons proposed by Wedhawati. The similarity of meaning is caused by a group of words that has a shared meaning component, namely a shared concept of 'MIND'. Then, in terms of form variation that distinguishes meaning is a sign that each word in the group has the specific component of meaning. That makes the existence of word diversity in expressing concept in a language. The method used is descriptive qualitative where verbal test was exercised in data collection. Verbal test is a test for gaining data applying some related contexts. From this analysis, a list of lexicon concept 'MIND' was obtained. The lexicons consist of 27 words with their exact definition. The definition of the lexicon is used to explain the different meanings contained in words that express 'activity of mind' in Javanese language.
\end{abstract}

Keywords: lexicon, meaning components, shared meaning, spesific meaning

\section{INTRODUCTION}

The realization of Javanese mindset in the Javanese lexicon shows diverse variation of vocabulary form. The diversity of lexeme formation is a reflection of Javanese clarity and accuracy in expressing a meaning of a concept. The more detailed and meticulous the expressed concept is, the more varied verbal forms are realized.

Mind activity is done by everybody. This activity is expressed in the form of words in a certain language. The Javanese mindset realized in Javanese lexicon shows variety of vocabulary forms and brooding of expressed concept

In order to have description of the realization of Javanese mindset in the Javanese lexicon, it requires scrutiny and understanding through an analysis. One good analysis employs observation and understanding of vocabulary through semantic analysis. Semantic analysis is an important thing to do because it can express diversity of a word concept. The result of semantic analysis can contribute to interesting things, particularly viewed in relation to cultural aspect or its user community culture.

For example, vocabulary that shows the concept of 'EARS ACTIVITY' is a word 'krungu' to hear ', dirungoni ' unintentionally to be heard', nguping 'to listen (while hiding)', krungu-krungu 'seems to hear news, nelingake 'to listen', mbudheg ' pretend not to listen '.

The semantic discussion on the vocabulary, in this case Javanese vocabulary, has been widely practiced around the 90s. The discussions are as follows: [1] Medan Makna Rasa dalam Bahasa Jawa; [2] Tipe-Tipe semantik Kata Kerja dalam Bahasa Jawa; [3]Medan Makna Aktivitas Tangan dalam Bahasa Jawa; Syamsul et al. 1990; Tipe-Tipe Semantik Adjektiva dalam Bahasa Jawa;"Medan Makna Aktivitas Panca Indera dalam Bahasa Jawa" [4]; and also a disertation by [5].

In addition, there is also a discussion of meaning field in Javanese in form of papers, among them, the writings summarized in the book Pelangi Linguistik (2012); Nurlina's paper [4] discusses vocabulary that shows the concept of 'HEADACHE' in Javanese; [4] discusses the expression of words that have the concept of'CURIOSITY

\section{THEORY AND METHOD}

The underlying theory used in this paper is component analysis. To complete filtering of differentiator meaning element of related words, context in which the words are used is considered.

Component analysis theory views that meaning of a word can be identified by contrastingit with other word meanings[6].[7]translated by Kancanawati (1989: 83) explains that meaning of a lexical element can be found by studying that element in contrast with other elements which have close relation, for example by grouping the elements.

(i) What is $\mathrm{X}$ activity $\mathrm{Y}$ (concept 'MIND ACTIVITY')? The context of question (i) raises the following contexts: (ii) and (iii) contexts.

(ii) Is $\mathrm{X}$ a form of mind activity?

(iii) Is $\mathrm{X}$ an activity with a specific differentiator? So, $\mathrm{X}$ is lexemes of $\mathrm{Y}$ activity concept 
Table 1. Mind Activity -Neutral Vocabulary

\begin{tabular}{|c|c|c|c|c|c|c|c|}
\hline \multirow[b]{2}{*}{ No. } & \multirow[b]{2}{*}{ Lexeme } & \multirow[b]{2}{*}{ Verb } & \multicolumn{5}{|c|}{ Meaning Component } \\
\hline & & & $\begin{array}{l}\text { Positive } \\
\text { mind }\end{array}$ & $\begin{array}{c}\text { Neutral } \\
\text { mental }\end{array}$ & Sincerity & Patience & Additional meaning \\
\hline 1. & Pikir & Mikir & + & + & + & + & analytical, reasoning \\
\hline 2. & Grahita & Nggraita & + & + & \pm & - & Guess \\
\hline 3. & Udarasa & Ngudarasa & + & + & \pm & - & Uncertain \\
\hline 4. & Nalar & Nalar & + & + & + & + & argumenta-tive \\
\hline 5. & Teges & Neges & + & + & + & + & Meaning \\
\hline 6. & Cipta & Nyipta & + & + & + & + & Productivity \\
\hline 7. & Ripta & Ngripta & + & + & + & + & Productivity \\
\hline 8. & Ening cipta & Ngeningake- cipta & + & + & + & + & Concentration \\
\hline 9. & Timbang & Nimbang-nimbang & + & + & \pm & + & Comparative \\
\hline 10. & Gagas & Nggagas & + & + & \pm & \pm & Predictive \\
\hline 11. & Angen-angen & Ngangen-angen & + & + & \pm & \pm & Hope \\
\hline 12. & Eling & Ngelingeling & + & + & + & + & Memory \\
\hline 13. & Eguh & Ngeguh & + & + & + & + & Solusive \\
\hline 14. & Trawang & Nrawang & + & + & \pm & + & Predictive \\
\hline 15. & Ngerti & Ngerti & + & + & + & $\underline{ \pm}$ & Know \\
\hline 16. & Cakep & Nyakep & + & + & + & + & Summarize \\
\hline 17. & Rigen & Ngrigen & + & + & + & + & Diligent \\
\hline 18. & Reka & Ngreka & + & + & + & + & Creative \\
\hline 19. & Tayuh & Nayuh & + & + & + & + & weigh, surrender \\
\hline 20. & Tanggap & Nanggapi & + & + & + & \pm & Responsive \\
\hline 21 & Srempeng & Nyrempeng & + & + & + & $\underline{ \pm}$ & Speed \\
\hline 22. & Prodong & mrodong-mrodong & + & + & - & + & thinking aloud \\
\hline 23. & Simak & Nyimak & + & + & + & + & $\begin{array}{l}\text { be careful/attentive } \\
\text { listening }\end{array}$ \\
\hline 24. & Apal & Ngapalake & + & + & + & + & Iterative \\
\hline 25 & Legewa & Nglegewa & + & + & - & - & unexpec-tedly \\
\hline 26. & Gati & Nggatekake & + & + & + & + & Attention \\
\hline 27. & Titi & Niteni & + & + & + & + & Brooding \\
\hline
\end{tabular}

From that study, component of shared meanings and component of its contrasting meaning (differentiator) aredescribed. Component of contrasting meaning is component of specific meaning.

In this analysis, actually form of analyzed data is a lexeme as a word candidate. Lexeme is defined as' 1 an abstract basic unit form underlying various word forms; 2 the smallest unit in the lexicon [8], (see, KBBI, 2008: $653 ;$ ).

This component of analysis has several semantic relations, such as synonymy, antonimy, and hyponimy.In relation to the discussion, analysis of meaning relationships discussed in this paper is relation of hyponimi, which is also called inclusion relationship [2].[2]in her dissertation is more appropriately applied to this study because the object of study is Indonesian and Javanese languages

The method used in this study is a descriptive qualitative method. The meanings of words that have concept of 'MIND ACTIVITY' are described qualitatively. Their qualitative content is described by contrasting their words meaning component with other words which are in the same field word component.
Regarding to contrasting, a technique of dividing determinant element is used with referential dividing, as described by [9].

In the data collection, text observation method on Javanese dictionary is used, which is supported by oral observation on speeches that use the words 'MIND ACTIVITY' concept in oral language.Then, a verbal test is used to determine the further analyzed data.This verbal test is a test to filter data by using several related contexts. Principally, the context is arranged in terms of data definition based on scope determination. It is called a test context.Therefore, the context to filter data is structured as follows. In meaning component analysis, the concerned context surrounding the use of lexeme is considered. In this data analysis step, a careful examination of data that has been classified based on components of meaning and sub-core is conducted. Furthermore, the observation is done by contrasting generic meaning component possession as a shared meaning component and specific meaning component.

The data arelexicons used to express meaning of mind activity in Javanese. The lexicon is derived from written and oral communication. It means that written 
data source is taken from several Javanese dictionaries. The data taken from Javanese magazines and conversations in Javanese are used as data for contextual usage examples.

\section{RESULT}

Here are some words that have meaning concept of 'MIND ACTIVITY' and their composition definitions.

\section{Vocabulary Concept of 'MIND ACTIVITY'}

The following is meaning analysis component of Javanese words that havemeaning concept of 'MIND ACTIVITY' '. Mind activity can be broken down into six groups: (a) mind-neutral, (b) mind-estimation (count), (c) mind-desire (intention), (d) mind-ability, (e) mind-deal, (f) mind-belief.Here is the lexicon of 'mind-neutral activity' group. The detail result can be seen in the following table.

\section{Meaning Composition of Vocabulary Concept of "MIND ACTIVITY"}

As a result of the lexicon field analysis, a collection of meaning components of each lexeme is gained. These components of meaning are not merely collected, but they have a composition that eventually composes a complete understanding of a lexeme.

The acquisition of meaning component is organized by preceding it with its core meaning component, which then includes its specific components. Therefore, a lexeme definition can be constructed. The definition here is presented as a composition of meaning informal redactional form. The results of the composition can be seen in the following description.

This 'mind-neutral' group has twenty-seven members of lexemes, namely pikir, grahita, udarasa, reason, creation, creation, ripta, eningcipta, nimbang-nimbang, thinking, angen2, eling, eguh, trawang, ngerti, cakep, rigen, reka, tayuh, responsive, srempeng, prodong, see, apal, legewa, gati, and titi. To be more clear, the group lexemes that have a common 'mind-neutral' meaning component are used in the sentence context

TABLE 2. List Of Lectures Of Thinking With Definition

\begin{tabular}{|c|c|c|}
\hline No. & Word & Definition \\
\hline 1. & mikir & $\begin{array}{l}\text { positive and neutral mind activity that has elements of sincerity, patience, and analytical } \\
\text { nature }\end{array}$ \\
\hline 2. & Nggraita & $\begin{array}{l}\text { positive and neutral mind activity that has elements of meaning with/without sincerity and } \\
\text { prediction }\end{array}$ \\
\hline 3. & ngudarasa & $\begin{array}{l}\text { positive and neutral mind activity that has elements of meaning with/without sincerity and } \\
\text { there is an element of uncertainty }\end{array}$ \\
\hline 4. & Nalar & positive and neutral mind activity that has elements of sincerity, patience, and argumentation \\
\hline 5. & Neges & $\begin{array}{l}\text { positive and neutral mind activity that has elements of sincerity, patience, and } \\
\text { meaningfulness }\end{array}$ \\
\hline 6. & Nyipta & positive and neutral mind activity that has elements of sincerity, patience, and productivity \\
\hline 7. & Ngripta & positive and neutral mind activity that has elements of sincerity, patience, and productivity \\
\hline 8. & ngeningake cipta & positive and neutral mind activity that has elements of sincerity, patience, and concentration \\
\hline 9. & nimbang-nimbang & $\begin{array}{l}\text { positive and neutral mind activity that has elements of meaning with/without sincerity, and } \\
\text { comparability }\end{array}$ \\
\hline 10. & Nggagas & $\begin{array}{l}\text { positive and neutral mind activity that has elements of meaning with/without sincerity, } \\
\text { with/without patience and prediction }\end{array}$ \\
\hline 12. & ngeling-eling & positive and neutral mind activity that has elements of sincerity, patience, and memory \\
\hline 14. & Nrawang & $\begin{array}{l}\text { positive and neutral mind activity that has elements of meaning with/without sincerity, } \\
\text { patience, and it is predictive }\end{array}$ \\
\hline 16. & Nyakep & positive and neutral mind activity that has element of sincerity, patience, and concise \\
\hline 17. & Ngrigen & positive and neutral mind activity that has element of sincerity, patience, and diligence \\
\hline 18. & Ngreka & positive and neutral mind activity that has the element of sincerity, patience, and creativity \\
\hline 19. & Nayuh & $\begin{array}{l}\text { positive and neutral mind activity that has elements of sincerity, patience, with } \\
\text { consideration, and a sense of concede }\end{array}$ \\
\hline 20. & nanggapi & $\begin{array}{l}\text { positive and neutral mind activity that has the meaning elements of sincerity, with/without } \\
\text { patience, and it is reactive }\end{array}$ \\
\hline 21. & nyrempeng & $\begin{array}{l}\text { positive and neutral mind activity that has an element of sincerity, with/without patience, and } \\
\text { speed }\end{array}$ \\
\hline 22. & mrodong-mrodong & positive and neutral mind activity that has elements of meaning without sincerity, patience, \\
\hline
\end{tabular}




\begin{tabular}{|l|l|l|}
\hline & & and think aloud \\
\hline 23. & Nyimak & $\begin{array}{l}\text { positive and neutral mind activity that has the elements of sincerity, patience, and } \\
\text { meticulousness }\end{array}$ \\
\hline 24. & ngapalake & positive and neutral mind activity that has the elements of sincerity, patience, and iteration \\
\hline 25. & nglegewa & $\begin{array}{l}\text { positive and neutral mind activity that has elements of meaning without sincerity, without } \\
\text { patience, and without prediction }\end{array}$ \\
\hline 26. & nggatekake & positive and neutral mind activity that has element of sincerity, patience, and attention \\
\hline 27. & Niteni & positive and neutral mind activity that has element of sincerity, patience, and carefulness \\
\hline
\end{tabular}

\section{CONCLUSION}

Based on the analysis andresult, the conclusion is as follows. Vocabulary in the form of lexemes with concept of 'MIND ACTIVITY' in Javanese language is the resultof expression of Javanese mind concept. The Javanese mind concept reflects culture of Javanese ethnic society that has a variety of minds. The concept is expressed in 27 lexemes (words).

Theresearch on the lexeme component analysis of 'mind activity' concept in Javanese is necessary. It concerns with various benefits. The most practical benefit is in relation to development of lexicography. Furthermore, the description can be applied in several ways as follows: (i) as the result of vocabulary inventory based on the lexical field; (ii) as a material for composing of Javanese dictionaries and thesauruses; (iii) as an aid for translation and language teaching; (iv) as an enrichment tool of language family (Austronesian family).

\section{REFERENCES}

[1]. Suwadji, dkk. Medan Makna Rasa dalam Bahasa Jawa. Jakarta: Departemen Pendidikan dan Kebudayaan.1995.

[2]. Wedhawati, dkk. Tipe-Tipe semantik Kata Kerja dalam Bahasa Jawa. Jakarta: Departemen Pendidikan dan Kebudayaan.1990.

[3]. Setyanto, Edi. Medan Makna Aktivitas Tangan dalam Bahasa Jawa. Jakarta: Departemen Pendidikan dan Kebudayaan.1997.

[4]. Nurlina, Wiwin Erni Siti."Leksikon Berkonsep Makna "Rasa Sakit pada Tubuh Khususnya di Kepala" dalam Bahasa Jawa: Analisis Komponen Makna" dalam Proceeding $\sigma^{\text {th }}$ International Seminar on Austronesian--non-Austronesian Languages and Literatures, Program Studi Linguistik, Pascasarjana, Universitas Udayana, Bali, 6-7 November 2013.).(2013).
[5]. Nurlina, Wiwin Erni Siti. 2016. "Kosa kata Berkonsep Makna 'Ingin' Dalam Bahasa Jawa" dalam Seminar Nasional Bahasa dan Sastra, (Proceeding) pada tanggal 1-3 November 2016 Maluku, Ambon

[6]. Wedhawati. "Medan Leksikal Verbal Indonesia yang Berkomponen Makna 'Suara Insani"'. (Disertation). Yogyakarta: PPs, Universitas Gadjah Mada. 1998.

[7]. Nida, Eugene. Componential Analysis of Meaning: Introduction to Semantic Structure. The Hague Mouton. 1975.

[8]. Larson, Mildred. Penerjemahan Berdasarkan Makna: Pedoman untuk Pemadana Antarbahasa. Terjemahan Kancanawati taniran, 1989, Jakarta: Penerbit Arcan. 1984.

[9]. Kridalaksana, H. Kamus Linguistik (keempat). Jakarta:PT Gramedia Pustaka Utama. (2008).

[10]. Sudaryanto. Metode dan Aneka Teknik Analisis Bahasa: Pengantar Penenlitian Wahana Kebudayaan secara Linguistik. Yogyakarta: Sanata Dharma University Press. 2015.

[11]. Aminuddin. Semantik: Pengantar Studi tentang Makna. Bandung: Sinar Baru. 1988.

[12]. Lehrer, A, Semantic Field and Lexical Structure. Amsterdam: North-Holland Publishing Company. 1974.

[13]. Nardiati, Sri. "Medan Makna Aktivitas Kaki". Yogyakarta: Proyek Pembinaan Bahasa dan Sastra Indonesia dan Daerah, Daerah Istimewa Yogyakarta. 1996. 